the first devoted to food web structure. My suspicion is that, ultimately, these big questions are entwined, so that we may not be able truly to understand what determines the length of food chains without understanding what determines the number of species, their relative abundance and their spectrum of physical sizes.

Robert M. May is Class of 1877 Professor of Zoology at Princeton University, New Jersey 08544 .

\title{
Atmospheric chemistry
}

\section{Increasing atmospheric methane}

from W.L. Chameides

IN the past few years there have been several reports ${ }^{1-4}$ that atmospheric methane levels, measured by the highly accurate gas chromatographic/flame ionization technique, have been increasing at the rate of 1.7 per cent per year since at least 1965 (refs 4,5). Now Craig and $\mathrm{Chou}^{4}$ have attempted to find out whether this is a short-term fluctuation or part of a longterm trend by taking polar ice cores and analysing air samples which were trapped in polar ice as far back as $27,000 \mathrm{BP}$. Their results lead to the startling conclusion that atmospheric methane concentrations remained fairly constant from $27,000 \mathrm{BP}$ to AD 1580 at 0.7 p.p.m.v. (parts per million by volume) - about half the present value of 1.65 p.p.m.v. In 1580 methane levels began to rise, first at a rate of about 0.114 p.p.m.v. per century and then, from 1915 , much more rapidly, at a rate of 2.5 p.p.m.v. per century, roughly equivalent to the rate of 1.7 per cent per year inferred from presentday measurements.

Should the approach of Craig and Chou prove to be valid - they make the assumption that methane trapped in ice is neither produced nor destroyed over tens of thousands of years, which, while not unreasonable, has yet to be validated - then their findings may have significant implications. An increase in methane from 0.7 p.p.m.v. to its present value of 1.66 p.p.m.v. is estimated to have caused an increase in global temperatures of about $0.23^{\circ} \mathrm{C}$ due to the atmospheric greenhouse effect $^{6}$. The temperature rise is roughly 38

\footnotetext{
1. Rasmussen, R.A. \& Khalil, M.A.K. J. geophys. Res. 86, 9826 (1981)

2. Seiler, W. Personal communication (1982)

3. Blake, D.R. et al. Geophys. Res. Lett. 9,477 (1982).

4. Craig, H. \& Chou, C.C. Geophys. Res. Lett. 9, 1221 (1982).

4. Craig, H. \& Chou, C.C. Geophys. Res. Lett. 9,1221 (1982). Graedel, T.E.
$977(1980)$.

6. Wang, W.C., Yung, Y.L., Lacis, A.A., Tho, T. \& Hansen, J.E. Science 194685 (1976)

7. Enhalt, D.H. Tellus 26, 58 (1974)

8. Levy, H. Science 173, 141 (1971).

9. Sze, N.D. Science 195, $673(1977)$

10. Chameides, W.L., Liu, S.C. \& Cicerone, R.J. J. geophys. Res. 82, 1795 (1977).
}

1. Cohen, J.E. Food Webs and Niche Space (Princeton University Press, 1978).

2. Pimm, S.L. Food Webs (Chapman \& Hall, 1982).

3. Rejmanek, M. \& Stary, P. Nature 280, 311 (1979).

4. Briand, F. Ecology (in the press)

5. Paine, R.T. J. Anim. Ecol. 49,667 (1980)

6. May, R.M. Nature 238, 413 (1972)

Pimm, S.L. \& Lawton, J.H. Nature 275, 542 (1978).

8. Sugihara, G. thesis, Princeton Univ. (1982).

9. Gardner, M.R. \& Ashby, W.R. Nature 228, 784 (1970).

10. Roberts, A.P. Nature 251607 (1974)

11. Tregonning, K. \& Roberts, A.P. Nature 281, 563 (1979).

12. Yodzis, P. Nature 284, 544 (1980).

13. Gilpin, M.E. \& Case, T. Nature 261,40 (1976).

14. Yodzis, P. J. theor. Biol. 92, 103 (1981).

15. De Angelis, D.L. Ecology 56, 238 (1975)

16. Pimm, S.L. \& Lawton, J.H. Nature 268, 329 (1977).

17. De Angelis, D.L., et al. Nature 273, 406 (1978).

18. Hastings, H.M. \& Conrad, M. Nature 282, 838 (1979).

19. Nunney, L. Am. Nat. 115, 639 (1980). caused methane suddenly to increase towards the end of the sixteenth century after remaining constant for at least 25,000 years? Why did the rate of increase accelerate in this century?

The primary sources of atmospheric methane are biogenic ${ }^{7}$ arising from the fermentation of organic material by anaerobic bacteria living in swamps, rice paddies, tropical rain forests and the intestinal tracts of livestock and termites. Methane is removed from the atmosphere photochemically by reaction with $\mathrm{OH}^{8}$ and approximately 200 million tons of methane are cycled through the atmosphere per cent of the increase calculated to have occurred as a result of increases in atmospheric $\mathrm{CO}_{2}$. Furthermore, since methane plays a central role in the chemistry of the atmosphere the increase may have caused changes in the levels of other atmospheric constituents such as $\mathrm{OH}, \mathrm{CO}$ and $\mathrm{O}_{3}$.

How can we explain the methane trends suggested by the data of Craig and Chou? What process or processes could have annually. Given a present-day methane abundance of 1.6 p.p.m.v., the atmospheric residence time for methane can be estimated at around 10 years.

One possible explanation of the increase is that atmospheric $\mathrm{OH}$, which acts to remove $\mathrm{CH}_{4}$ from the atmosphere, has decreased in concentration over this time period $^{9,10}$. Alternatively, the increasing $\mathrm{CH}_{4}$ concentrations could be due to increasing biogenic production rates of $\mathrm{CH}_{4}$. It is known, for instance, that as the world's population and demand for food has grown over the past centuries, the population of livestock and the total area of the world under rice paddy cultivation has also grown, implying a corresponding increase in methane production ${ }^{7}$. Should this latter explanation be correct it is likely that methane levels will continue their upward trend in the coming decades. We can only speculate as to the effects it will have on climate and global chemical cycles.

W.L. Chameides is an Associate Professor of Geophysics in the School of Geophysical Sciences, Georgia Institute of Technology, Atlanta, Georgia 30332.

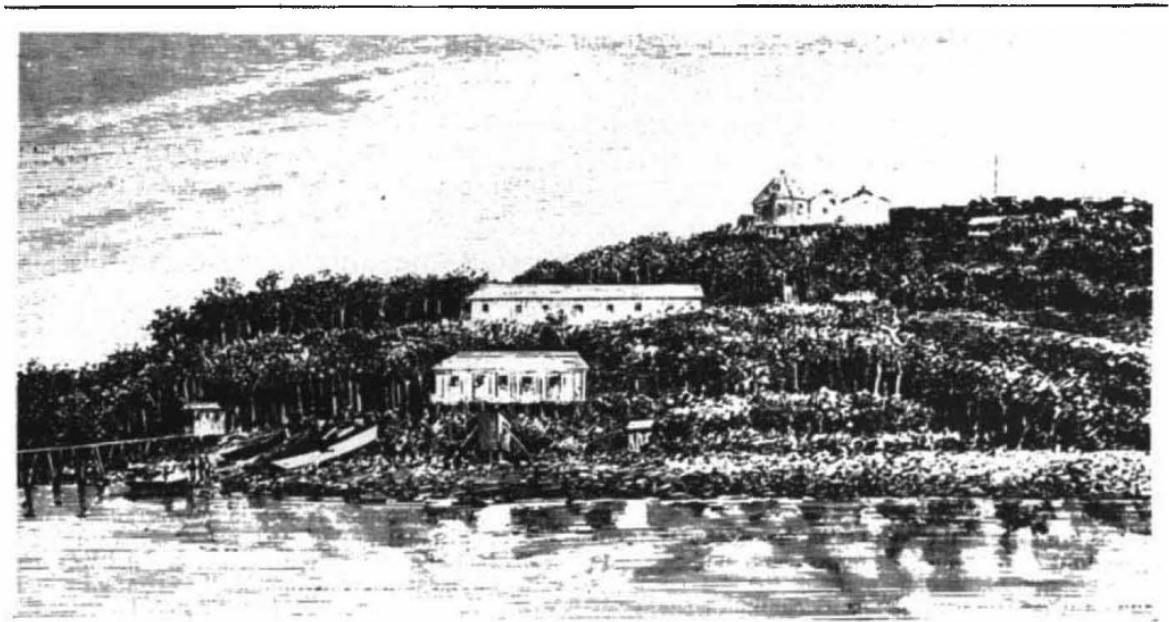

\section{0 years ago}

\section{THE FRENCH MISSION TO CAPE HORN}

THE members of the French Magnetic and Meteorological Expedition to Cape Horn have taken up their quarters at Crange Bay, and have already begun work. The accompanying illustration, reproduced from La Nature, after a photograph transmitted to the Paris Academy of Sciences, will give an idea of the aspect of the station occupied by the expedition. On the summit of the hill are the astronomical cabins, beside which are placed a pluviometer and an actinometer. The large house in the middle distance forms the officers' quarters, while the lower building is for the sailors. Along the shore are other structures partly shown in the illustration, a stockade for the tidal register, and an isolated tent for absolute determinations.

The mission arrived at Orange Bay, Terra del Fuego, on September 6 last. They found the country marshy, and were compelled to select a wooden spot in order to obtain firm ground. No time was lost in erecting in-closings and installing the various instruments; and on September 26, the meteorological and magnetical observations were begun.

From Nature 27, 344, 8 February, 1883 